\title{
Recurrent selection resulted in rapid genetic gain for upland rice in Brazil
}

\author{
F. Breseghello, O.P. Morais, E.M. Castro, A.S. Prabhu, and P.Z. Bassinello, Embrapa Rice and \\ Beans; J.A. Pereira, Embrapa Mid-North; M.M. Utumi, Embrapa Rondônia; M.E. Ferreira, \\ Embrapa Genetic Resources and Biotechnology; and A.A. Soares, Federal University of Lavras
}

Populational recurrent selection (RS) has been used for rice breeding at the Brazilian Agricultural Research Corporation (Embrapa) since the early 1990s. One of the populations under RS is named CG3, developed in 1997 by intercrossing 59 selected families, representing Embrapa's elite early-flowering upland rice germplasm. This note reports the results of the ongoing RS applied to the CG3 population.

The RS scheme is based on a 3-year, four-step cycle (Fig. 1)-year 1 selection of $\mathrm{F}_{1}$ single plants; year 2 selection between $F_{2}$ progenies to advance to yield trials and selection of five plants within selected $F_{2}$ progenies, of which $\mathrm{F}_{3}$ seeds are kept in storage; year 3 , evaluation of $250-300 \mathrm{~F}_{1: 3}$ families, in multiple-environment yield trials; and off-season recombination of approximately 50 selected $\mathrm{F}_{1: 3}$ families, by manual crossing, using $\mathrm{F}_{2: 3}$ seeds in storage. Single-plant selection was based on plant architecture, phytosanitary aspect, and grain type, whereas family-based selection depended on grain yield, lodging resistance, heading date, disease

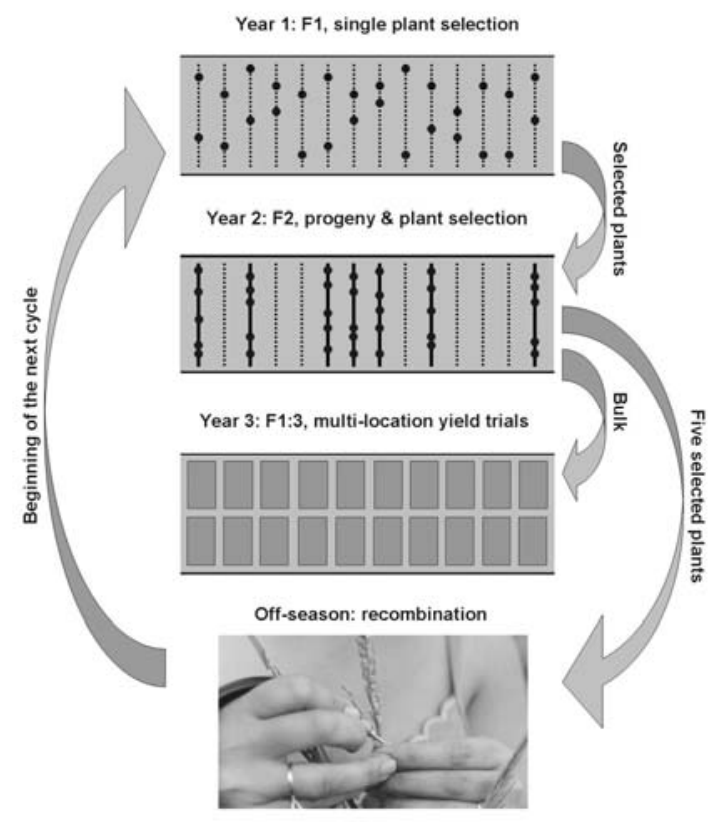

Fig. I. Recurrent selection scheme used for upland rice improvement at Embrapa. resistance, and grain quality.

The results reported here are based on data from field evaluation of $F_{1: 3}$ families in three RS cycles (trials in 2000, 2003, and 2006), conducted in four to five environments/year, in an augmented block design (Federer 1961), with four 
early-flowering rice cultivars used as checks, replicated in each block. Plots were dry-seeded in 4 rows $\times 5 \mathrm{~m}$, spaced at $0.3 \mathrm{~m}$, with 60 seeds $\mathrm{m}^{-1}$. Data were analyzed in SAS/GLM, with the interactions family $\times$ cycle and family $\times$ environment within a cycle bulked into the experimental error. Genetic gain was estimated by comparing the adjusted means for each cycle (Breseghello et al 1998, modified by Morais et al 2000).

RS resulted in rapid gain for grain yield (Table 1). In cycle 1, the mean yield of $\mathrm{F}_{1: 3}$ families from the population was significantly lower than the mean of the checks. In cycle 2, there was no significant difference. In cycle 3, the population was more productive than the checks. The mean genetic gain for grain yield was $103.4 \mathrm{~kg} \mathrm{ha}^{-1} \mathrm{y}^{-1}$, corresponding to $3.6 \%$ of the initial population mean. This gain is three to four times as high as the genetic gain from other rice breeding programs in Brazil, using pedigree schemes (Breseghello et al 1999). Some increase in days to flowering was observed, whereas plant height showed a small change. Lodging and blast disease severity decreased significantly in the population (data not shown).

Table I. Adjusted means of groups of families from the population CG3, evaluated in three cycles of recurrent selection, compared with the mean of checks, for grain yield, flowering time, and plant height.

\begin{tabular}{|c|c|c|c|c|c|c|c|c|}
\hline \multirow[t]{2}{*}{ Group } & \multirow[t]{2}{*}{ Year } & \multirow{2}{*}{$\begin{array}{c}\text { Number } \\
\text { of materials }\end{array}$} & \multicolumn{2}{|c|}{ Grain yield } & \multicolumn{2}{|c|}{ Flowering time } & \multicolumn{2}{|c|}{ Plant height } \\
\hline & & & $\left(\mathrm{t} \mathrm{ha}^{-1}\right)$ & $(\%)$ & (days) & $(\%)$ & $(\mathrm{cm})$ & $(\%)$ \\
\hline Checks & Average & 4 & $3.18 \mathrm{~b}$ & 100 & $76.9 \mathrm{a}$ & 100 & $104 \mathrm{~b}$ & 100 \\
\hline $\begin{array}{l}\text { Cycle I } \\
\text { families }\end{array}$ & 2000 & $13 \mid$ & $2.87 \mathrm{c}$ & 90 & $71.3 \mathrm{~d}$ & 93 & $105 \mathrm{ab}$ & 101 \\
\hline $\begin{array}{l}\text { Cycle } 2 \\
\text { families }\end{array}$ & 2003 & 269 & $3.19 \mathrm{~b}$ & 100 & $73.3 \mathrm{c}$ & 95 & $106 \mathrm{a}$ & 102 \\
\hline $\begin{array}{l}\text { Cycle } 3 \\
\text { families }\end{array}$ & 2006 & 244 & $3.49 \mathrm{a}$ & 110 & $74.7 \mathrm{~b}$ & 97 & $105 \mathrm{a}$ & 101 \\
\hline $\begin{array}{l}\text { Gain per } \\
\text { year }\end{array}$ & & & 0.103 & 3.6 & 0.6 & 0.8 & 0.0 & 0.0 \\
\hline
\end{tabular}

Yield histograms of families from each cycle revealed an increasing mean and a somewhat decreasing variance in grain yield (Fig. 2). Maintenance of genetic variation is important in populational breeding. To evaluate the remaining variability in CG3, $96 \mathrm{~F}_{1: 4}$ families were genotyped with three fluorescent-based multiplexes, comprising 15 SSR markers (Pessoa Filho et al 2007). Each family was represented by a bulk of six plants. The number of alleles was computed as total, common, and effective alleles. Results indicated an 
intermediate to high remaining genetic diversity (Table 2), which should allow further gains through RS.

Two factors may have contributed to the rapid gains observed: (1) in the first two cycles of selection, low-yielding families were easily detected and eliminated, raising the population mean; (2) blast disease incidence in the checks increased through the cycles, and the consequent decay in the performance of the checks may have partially inflated the estimate of genetic gain. Nevertheless, the improvement in CG3 is corroborated by the fact that the best inbred lines from cycle 3 are proving to be competitive with elite lines from the pedigree program (evaluation in progress).
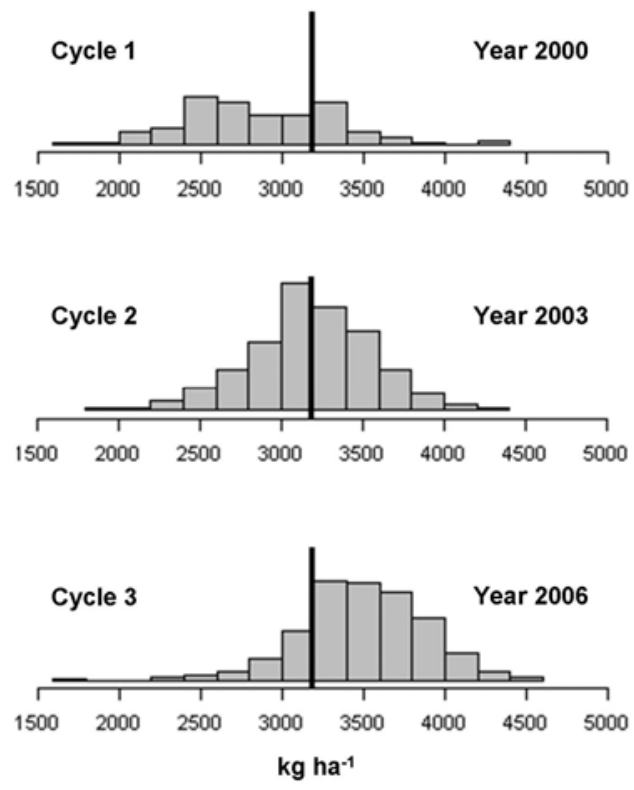

Fig. 2. Histograms of the distribution of grain yield of $\mathrm{FI}: 3$ families from upland rice population CG3 in three consecutive cycles of recurrent selection. Heavy lines indicate the adjusted mean of four checks across cycles.

Table 2. Number of total, common, and effective alleles detected in the populations of CG3 on I 5 unlinked SSR loci.

\begin{tabular}{lccc}
\hline Marker & \multicolumn{3}{c}{ Alleles (no.) } \\
\cline { 2 - 4 } & $\begin{array}{c}\text { Total } \\
\text { (all alleles) }\end{array}$ & $\begin{array}{c}\text { Common } \\
\left(\mathrm{p}_{\mathrm{i}}>5 \%\right)^{\mathrm{a}}\end{array}$ & $\begin{array}{c}\text { Effective } \\
\left(\mathrm{Ne}=1 / \Sigma \mathrm{pi}^{2}\right)\end{array}$ \\
\hline OG05 & 6 & 2 & $\mathrm{I}$ \\
OG106 & $1 \mathrm{I}$ & 5 & 4.5 \\
OG44 & $\mathrm{II}$ & 7 & 4.7 \\
OG61 & 8 & 4 & 3.9 \\
OG8I & 7 & 4 & 2.4 \\
OS19 & 6 & 3 & 2.0 \\
RM224 & 13 & 5 & 4.5 \\
RM248 & 10 & 3 & 2.0 \\
RM252 & 5 & 2 & 2.0 \\
RM259 & 9 & 3 & 1.3 \\
RM263 & 4 & 3 & 2.4 \\
RM335 & 9 & 5 & 3.1 \\
RM418 & 5 & 3 & 2.2 \\
RM420 & 5 & 2 & 1.9 \\
RM475 & 5 & 2 & 1.5 \\
\hline Av & 7.6 & 3.5 & 2.64 \\
\hline${ }^{2}$ pi=frequency of the i ${ }^{\text {th }}$ allele. &
\end{tabular}


Considering the progress achieved so far and the remaining genetic variability in the population, it is reasonable to expect that inbred lines from CG3 may soon take the yield of upland rice beyond current levels in Brazil.

\section{References}

Breseghello F, Morais OP, Rangel PHN. 1998. A new method to estimate genetic gain in annual crops. Genet. Mol. Biol. 21:551-555.

Breseghello F, Rangel PHN, Morais OP. 1999. Yield gain through irrigated rice breeding in northeast Brazil. Pesq. Agropecu. Bras. 34:399-407.

Federer WT. 1961. Augmented designs with one-way elimination of heterogeneity. Biometrics 17:447-473.

Morais OP, Zimmermann FJP, Rangel PHN. 2000. Evaluación de ganancias observadas en selección recurrente. In: Guimarães EP (ed.). Avances en el mejoramiento poblacional en arroz. S. Antonio de Goiás, Embrapa Arroz e Feijão. p 21-35.

Pessoa Filho MA, Belo A, Alcochete A, Rangel PHN, Ferreira ME. 2007. A set of multiplex panels of microsatellite markers for rapid molecular characterization of rice accessions. BMC Plant Biol. 7:23. 